\title{
FAKTOR FAKTOR YANG MEMPENGARUHI LAYANAN RESERVASI HOTEL DI PT. BALI MEGAH WISATA TOUR AND TRAVEL
}

\author{
Si Gede Ngurah Bramantya Agustiano \\ I Made Kusuma Negara \\ I Wayan Suardana \\ Email : bramagustiano@yahoo.com \\ PS. S1 Industri Perjalanan Wisata \\ Fakultas Pariwisata UNUD
}

\begin{abstract}
This study aims to determine the factors that influence hotel reservation service at Bali Megah Wisata Tour and Travel and a contributing factor dominant in hotel reservation service at Bali Megah Wisata Tour and Travel. The respondents in this study use purposive sampling technique in which the criteria are tourists who have made hotel reservation at Bali Megah Wisata Tour and Travel, with the total sample of 190 respondents. Questionnaires were used to collect data have been tested for validity and reliability. The data analysis which is used to answer the hypothesis of this study is factor analysis.

The results of factor analysis showed that 5 factors affecting hotel reservation service at Bali Megah Wisata Tour and Travel are structur and ease of use factor with eigen value 6,492, reputation and security factor with eigen value 2,671, usefulness factor with eigen value 2,497, information content factor with eigen value 1,889 and responsiveness and personalization factor with eigen value 1,059. Structure and ease of use factor is a contributing factor dominant in hotel reservation service at Bali Megah Wisata Tour and Travel.
\end{abstract}

Keywords : Quality Service, Hotel Reservation.

\section{PENDAHULUAN}

Pariwisata merupakan salah satu sektor yang menjadi pilihan bagi negaranegara yang berkembang dalam rangka mewujudkan masyarakat yang sejahtera dan makmur disamping sektor lain. Indonesia dengan keanekaragaman budaya, kekayaan alam serta keramah-tamahan penduduknya merupakan potensi dalam kepariwisataan. Bali merupakan salah satu destinasi yang paling terkenal di Indonesia telah mendapatkan perhatian pemerintah dalam pengembangan potensi pariwisatanya. Hal ini dapat dilihat dari semakin berkembangnya sarana dan prasarana pariwisata seperti akomodasi, transportasi, fasilitas rekreasi, teknologi informasi dan komunikasi serta atraksi wisata. Kemajuan perkembangan pariwisata yang ada, menjadi daya tarik tersendiri bagi wisatawan untuk melakukan kegiatan pariwisata di Bali. Selain itu budaya dan adat istiadat yang kental hingga kini masih menjadi andalan di dalam meningkatkan jumlah kunjungan wisatawan ke Bali.
Semua komponen utama pariwisata seperti akomodasi, transportasi, atraksi, travel agent dan penunjang pariwisata saat ini tidak terlepas akan penggunaan teknologi informasi seperti penggunaan internet di dalam memasarkan produknya. Penerapan teknologi informasi ini telah menjangkau semua lapisan atau sektor, terutama sektor pariwisata yang melibatkan bisnis lintas negara yang mana dalam menjual produknya mengandalkan informasi dari segala sumber. Dengan kemajuan teknologi informasi, calon konsumen dapat melakukan reservasi online secara mudah dan dimana saja.

Penggunaan reservasi online sudah banyak diterapkan pada industri yang bergerak dalam bidang pariwisata terutama biro perjalanan wisata. Dengan adanya reservasi online akan membantu biro perjalanan wisata untuk memposisikan diri serta bersaing dalam memberikan pelayanan yang berkualitas dan memudahkan pengguna atau calon wisatawan untuk melakukan reservasi dengan harapan calon wisatawan mendapatkan kepuasan dan 
dapat meningkatkan transaksi pembelian oleh calon wisatawan tersebut terhadap biro perjalanan wisata.Salah satu biro perjalanan wisata yang memanfaatkan reservasi online adalah PT. Bali Megah Wisata Tour and Travel.

Pelayanan reservasi online di PT. Bali Megah Wisata Tour and Travel berdasarkan hasil observasi menunjukan bahwa koneksi internet yang dimiliki oleh PT. Bali Megah Wisata Tour and Travel sering mengalami gangguan dengan kecepatan internet yang kurang dari 1 Mbps dengan layanan internet Telkom Speedy, serta penggunaan komputer yang terlalu banyak membuat kecepatan internet menjadi lambat sehingga menghambat dalam melakukan reservasi. Hal itu juga berpengaruh terhadap pelayanan lewat e-mail seperti membalas pesanan wisatawan dan informasi ketersediaan kamar hotel. Dari permasalahan tersebut, penting untuk meneliti terhadap faktor-faktor yang dapat mempengaruhi layanan reservasi hotel di PT. Bali Megah Wisata Tour and Travel sehingga nantinya mampu meningkatkan jumlah kunjungan wisatawan yang melakukan reservasi hotel.

\section{TINJAUAN PUSTAKA}

\section{Tinjauan Tentang Layanan}

Menurut Napitupulu (2007 : 164) pelayanan adalah serangkaian kegiatan suatu proses pemenuhan kebutuhan orang lain secara lebih memuaskan berupa produk jasa dengan sejumlah ciri seperti tidak terwujud, cepat hilang, lebih dapat dirasakan daripada memilki, dan pelanggan lebih dapat berpartisispasi aktif dalam proses mengkonsumsi jasa tersebut.

\section{Tinjauan Tentang Reservasi Hotel}

Menurut Adi Soenarno (1995 : 160), istilah reservation atau reservasi adalah pemesanan tempat atau kamar sebelum menginap di hotel. Hal itu dilakukan tamu supaya mendapat tempat (kamar) yang dikehendaki atau supaya tidak kehabisan tempat (kamar) pada waktu datang di hotel.

\section{Tinjauan Tentang Biro Perjalanan Wisata}

Menurut Buchari (2005 : 350) menjelaskan Biro Perjalanan Wisata adalah suatu perusahaan yang menyelenggarakan, merencanakan dan mengurus segala sesuatu mengenai perjalanan, pengadaan penginapan, dan hiburan bagi wisatawan atau orang-orang yang mengadakan perjalanan.

\section{METODE PENELITIAN}

Penelitian ini menggunakan teknik pengumpulan data dengan observasi dan kuesioner. Teknik purposive sampling digunakan dalam penelitian ini dimana yang menjadi kriteria adalah wisatawan yang pernah melakukan reservasi hotel di PT. Bali Megah Wisata Tour and Travel, dengan jumlah sampel sebanyak 190 responden. Teknik pengumpulan data adalah kuisioner. Teknik analisis data yaitu analisis faktor.

\section{HASIL DAN PEMBAHASAN \\ Karakteristik Wisatawan}

Karakteristik wisatawan yang melakukan reservasi hotel di PT. Bali Megah Wisata Tour and Travel, laki-laki dengan jumlah 103 orang adalah yang paling mendominasi berdasarkan jenis kelamin dengan persentase $54,22 \%$, berdasarkan tingkat pendidikan S1 mendominasi dengan jumlah 94 orang atau 49,47\%, berdasarkan tingkat pekerjaan pegawai swasta mendominasi dengan jumlah 48 orang atau $25,27 \%$, liburan merupakan tujuan wisatawan datang ke Bali yang paling mendominasi dengan jumlah 103 orang atau 54,22 \%, sumber informasi tentang PT. Bali Megah Wisata Tour and Travel yang paling mendominasi adalah melalui internet dengan jumlah 73 orang atau $38,44 \%$, durasi tinggal 4 sampai 6 hari mendominasi dengan jumlah 102 dengan skor 53,68\%, hotel berbintang merupakan tempat menginap paling mendominasi dengan jumlah 119 dengan skor $62,63 \%$ dan biaya liburan $>5$ juta paling mendominasi dengan jumlah 152 dengan skor $80 \%$.

\section{Uji Validitas dan Reliabilitas Instrumen}

Hasil uji validitas menunjukkan bahwa keseluruhan indikator yang digunakan memiliki nilai korelasi diatas 0,3 sehingga keseluruhan indikator yang digunakan dinyatakan valid digunakan untuk mengukur faktor-faktor yang diteliti. Hasil uji reliabilitas dalam penelitian ini memiliki nilai cronbach's alpha 0,890 yang berarti bahwa instrumen 
tersebut dikatakan reliabel dimana instrumen layak digunakan untuk mengumpulkan data.

\section{Faktor-Faktor yang Mempengaruhi Layanan Reservasi Hotel di PT. Bali Megah Wisata Tour and Travel \\ Analisis Faktor}

Analisis data yang digunakan dalam penelitian ini adalah analisis faktor. Analisis faktor merupakan independent technique yaitu teknik analisis multivariate untuk melacak (exploratory) hubungan dari seluruh independent variable (butir item) dengan variabel lainnya. tahapan yang dilakukan sebagai berikut :

\section{Merumuskan Masalah}

Skor penilaian skala sikap dalam penelitian ini menggunakan skala Likert. Jumlah sampel penelitian ditentukan dengan menggunakan purposive sampling sebanyak 190 orang wisatawan. Terdapat 19 indikator dalam penelitian ini. Indikator dan data yang diperoleh dianalisis dengan menggunakan model analisis faktor.

\section{Membuat Matrik Korelasi}

Data yang masuk diolah menggunakan analisis faktor akan menjadi matrik korelasi. Hasilnya digunakan untuk mengidentifikasi indikator-indikator yang saling berhubungan. Indikator-indikator yang tidak terhubung dengan indikator lainnya akan dihilangkan. Indikator yang telah terhubung dapat diuji dengan melihat Determinant of Correlation Matrix yang mendekati 0, nilai KMO (KaiserMeyer-Olkin) harus lebih besar atau sama dari 0,5, nilai besaran Bartlett's Test of Sphericity pada signifikan $<0,05$ memperlihatkan hubungan diantara indikator-indikator tersebut sangat signifikan, uji Measure of Sampling Adequency (MSA) dengan kriteria MSA $\geq 0,5$ menunjukkan derajat korelasi antar indikator yang erat.

Hasil determinasi matrik korelasi menunjukkan angka 0 yaitu sebesar 0,009 . Hal ini menunjukkan bahwa diantara indikator saling terhubung. Kaiser-Meyer-Olkin (KMO) $=0,785$ menunjukkan bahwa pengambilan sampel cukup memadai dengan menggunakan analisis faktor dalam matrik korelasi karena nilai KMO di atas 0,50. Hasil Bartlett's Test of Sphericity $=2653,069$ pada signifikan $=0,000$. Hasil ini menunjukkan bahwa antar indikator terjadi korelasi (signifikan $<0,05$ ), sehingga model faktor dapat digunakan. Hasil dari Measure of Sampling Adequency (MSA) adalah 19 indikator memenuhi kriteria MSA $\geq$ 0,5 yang memperlihatkan hubungan antar indikator benar-benar erat.

\section{Menentukan Jumlah Faktor}

Indikator disusun sesuai dengan korelasi hasil pada langkah ke 2 untuk memperhitungkan jumlah faktor untuk mewakili data. Menentukan berapa faktor harus sesuai dengan besarnya eigen value tiaptiap faktor yang akan muncul. Dengan metode Principal Componen Analisis (PCA) didapat 5 faktor yang dapat mempengaruhi layanan reservasi hotel di PT. Bali Megah Wisata Tour and Travel. Berdasarkan hasil metode Principal Componen Analisis (PCA), eigen value berada pada interval 1,059 sampai 6,492.

Kelima faktor tersebut merupakan faktorfaktor yang mempengaruhi layanan reservasi hotel di PT. Bali Megah Wisata Tour and Travel. Berdasarkan eigen value, faktor paling representatif untuk mewakili kelompok variabel adalah faktor 1 dilihat dari yang paling besar yakni 6,492. Berdasarkan pada nilai percent of variance, yang menyumbang keseluruhan analisa adalah faktor 1 yakni $34,170 \%$. Nilai total cumulative of variance sebanyak $76,881 \%$ yang dipergunakan untuk menjelaskan kelima faktor yang memberikan pengaruh terhadap layanan reservasi hotel di PT. Bali Megah Wisata Tour and Travel.

\section{Rotrasi Faktor}

Rotasi faktor digunakan untuk menyederhanakan matrik faktor yang memiliki struktur yang sulit untuk diinterpretasikan. Karena itu, harus dilakukan rotasi faktor agar diperoleh struktur sederhana hingga mudah untuk menjelaskan keseluruhan faktor yang dianalisa dalam model. Rotasi varimax digunakan karena hasilnya mudah dianalisis baik secara teori ataupun sejalan dengan penelitian terdahulu dan bersifat orthogonal.

\section{Interpretasi Faktor}

Penggunaan interpretasi faktor dilakukan dengan mengelompokkan indikator yang memiliki faktor loading minimal 0,5 , danindikator yang memiliki faktor loading kurang dari 0,5 harus dikeluarkan. Hasil rotasi faktor terdapat 19 indikator yang mempunyai 
faktor loading $>0,5$ yang tersebar pada 5 faktor pada prosentase variance 76,881\%. Angka ini memperlihatkan bahwa penelitian ini mampu memperlihatkan faktor-faktor yang mempengaruhi layanan reservasi hotel di PT. Bali Megah Wisata Tour and Travel sebesar $76,881 \%$.

Sumbangan masing-masing faktor dan variabel secara rinci dapat dijelaskan sebagai berikut : Faktor structur and ease of use termasuk faktor-faktor yang mempengaruhi layanan reservasi hotel di PT. Bali Megah Wisata Tour and Travel (eigen value $=6,492$ ) yang terdiri dari indikator kemudahan pemesanan kamar secara online, kemudahan pembatalan kamar hotel secara online, kemudahan dalam mengakses sistem reservasi hotel, informasi mata uang pada sistem reservasi hotel dan berbagai macam pilihan hotel yang bekerjasama dengan biro perjalanan wisata. Faktor ini menjelaskan keragaman dari variabel sebesar 34,170\%.

Faktor reputation and security termasuk faktor-faktor yang mempengaruhi layanan reservasi hotel di PT. Bali Megah Wisata Tour and Travel (eigen value $=2,671$ ) yang terdiri dari indikator keamanan pembelian secara online, menyimpan informasi pribadi untuk pelanggan tetap, pengakuan terhadap citra biro perjalanan wisata, kejelasan informasi tentang biro perjalanan wisata, keakuratan dari informasi yang diberikan sistem reservasi hotel dan berbagai macam perbandingan harga untuk kamar hotel. Faktor ini menjelaskan keragaman dari indikator sebesar 14,057\%.

Faktor usefulness termasuk faktor-faktor yang mempengaruhi layanan reservasi hotel di PT. Bali Megah Wisata Tour and Travel (eigen value $=2,497$ ) yang terdiri dari indikator berbagai macam metode pembayaran online, kecepatan sistem reservasi hotel dalam menampilkan isi atau konten secara keseluruhan dan pelayanan lewat e-mail. Faktor ini menjelaskan keragaman dari indikator sebesar 13,143\%.

Faktor information content termasuk faktor-faktor yang mempengaruhi layanan reservasi hotel di PT. Bali Megah Wisata Tour and Travel (eigen value $=1,889$ ) yang terdiri dari indikator kejelasan informasi sistem reservasi hotel, membalas reservasi wisatawan dan tampilan sistem reservasi hotel yang rapi dan terstruktur. Faktor ini menjelaskan keragaman dari indikator sebesar 9,940\%.
Faktor responsiveness and personalization termasuk faktor-faktor yang mempengaruhi layanan reservasi hotel di PT. Bali Megah Wisata Tour and Travel (eigen value $=1,059$ ) yang terdiri dari indikator perhatian terhadap permintaan wisatawan dan berbagai macam penawaran diskon untuk harga kamar hotel. Faktor ini menjelaskan keragaman dari indikator sebesar 5,571\%.

\section{Ketetapan Model}

Model faktor perlu diuji ketepatannya untuk mengetahui apakah model mampu menjelaskan dengan akurat. Pengujiannya dengan prosentase jumlah residual yakni perbedaan nilai korelasi awal dengan korelasi hasil reproduced. Hasilnya diketahui bahwa nilainya adalah $15 \%$ atau sebanyak 26 residual yang menunjukan bahwa model faktor bisa diterima.

\section{SIMPULAN DAN SARAN Simpulan}

Faktor structur and ease of use diwakili oleh indikator kemudahan pemesanan kamar hotel secara online dengan faktor loading 0,938, faktor reputation and security diwakili oleh indikator keamanan pembelian secara online dengan faktor loading 0,758, Faktor usefulness diwakili oleh indikator berbagai macam metode pembayaran online dengan faktor loading 0,942, Faktor information content diwakili oleh indikator kejelasan informasi sistem reservasi hotel dengan faktor loading 0,910, Faktor responsivenss and personalization diwakili oleh indikator perhatian terhadap permintaan wisatawan dengan faktor loading 0,913.

Sedangkan hasil analisis faktor menunjukan bahwa structur and ease of use mempunyai nilai varian yang paling besar dari faktor-faktor lainnya yaitu 6,492, sehingga faktor structur and ease of use merupakan faktor yang berkontribusi dominan dalam layanan reservasi hotel di PT. Bali Megah Wisata Tour and Travel.

\section{Saran}

Berdasarkan hasil analisis faktor, indikator perhatian terhadap permintaan wisatawan dan penawaran diskon untuk harga kamar hotel masuk kategori paling rendah. Hal tersebut menunjukan bahwa perhatian terhadap permintaan wisatawan dan penawaran diskon 
untuk harga kamar hotel masih kurang baik. Perlu bagi PT. Bali Megah Wisata Tour and Travel untuk mengganti paket internet yang lebih baik agar tidak terjadi gangguan yang menyebabkan complain dari wisatawan sehingga perhatian terhadap permintaan wisatawan seperti penanganan booking kamar hotel, penanganan pembatalan kamar hotel dan permintaan perubahan jenis kamar bisa ditingkatkan lagi.

Selain itu perlu juga adanya penawaran diskon untuk harga kamar hotel seperti penawaran diskon pada saat high season agar wisatawan senang menggunakan jasa PT. Bali Megah Wisata Tour and Travel dan bisa meningkatkan jumlah kunjungan wisatawan dalam melakukan reservasi hotel.

\section{DAFTAR PUSTAKA}

Buchari, Alma.2005. Manajemen Pemasaran dan Pemasaran Jasa. Edisi Revisi, Cetakan Ketujuh. Bandung : Alfabeta.

Napitupulu, Paimin. 2007. Pelayanan Publik dan Customer Statisfiction. Bandung : PT. Alumni.

Soenarno, Adi. 1995. Kamus Istilah Pariwisata dan Perhotelan. Bandung : Angkasa. 